\title{
PENGARUH PROFITABILITAS, KEBIJAKAN HUTANG, DANLIKUIDITAS TERHADAP NILAI PERUSAHAAN PROPERTI DAN REAL ESTATE
}

\section{(Studi Empiris Pada Perusahaan Properti dan Real Estateyang Terdaftar di Bursa Efek Indonesia Tahun 2010-2016)}

\author{
Verdian$^{1}$, Heri Ispriyahadi $^{*}$ \\ ${ }^{1}$ Universitas Mercu Buana, mars liang 1987@yahoo.com \\ ${ }^{2}$ STIE Muhammadiyah Jakarta, herivirpat64@gmail.com (Corresponding Author)
}

\begin{abstract}
ABSTRAK
Penelitian ini mengkaji pengaruh profitabilitas, kebijakan hutang, dan likuiditas terhadap nilai perusahaan pada perusahaan property dan real estate di Bursa Efek Indonesia. Data dalam penelitian ini adalah data tahunan dengan periode 2010 hingga 2016. Metode pengambilan sampel yang digunakan adalah purposive sampling, dimana dari populasi perusahaan properti dan real estate yang terdaftar di Bursa Efek Indonesia sebanyak 49 perusahaan, dipilih 32 perusahaan sebagai sampel penelitian. Variabel independen dalam penelitian ini adalah profitabilitas (ROE), likuiditas (CR), dan kebijakan utang (DER). Variabel terikat dalam penelitian ini adalah nilai perusahaan (PBV). Metode analisis data yang digunakan dalam penelitian ini adalah analisis regresi data panel. Hasil penelitian menunjukkan bahwa ROE, DER, dan CR berpengaruh signifikan terhadap PBV secara simultan. Secara parsial ROE dan DER berpengaruh besar terhadap PBV, sedangkan CR tidak berpengaruh besar terhadap PBV. Penelitian ini meneliti pengaruh profitabilitas, kebijakan hutang, dan likuiditas terhadap nilai perusahaan terhadap perusahaan property dan real estate di Bursa Efek Indonesia. Data dalam penelitian ini adalah data tahunan dengan periode 2010 hingga 2016. Metode pengambilan sampel yang digunakan adalah purposive sampling, dimana dari populasi perusahaan properti dan real estate yang terdaftar di Bursa Efek Indonesia sebanyak 49 perusahaan, dipilih 32 perusahaan sebagai sampel penelitian. Variabel independen dalam penelitian ini adalah profitabilitas (ROE), likuiditas (CR), dan kebijakan utang (DER). Variabel terikat dalam penelitian ini adalah nilai perusahaan (PBV). Metode analisis data yang digunakan dalam penelitian ini adalah analisis regresi data panel. Hasil penelitian menunjukkan bahwa ROE, DER, dan CR berpengaruh signifikan terhadap PBV secara simultan. Secara parsial ROE dan DER memiliki pengaruh yang besar terhadap PBV, sedangkan CR tidak berpengaruh besar pada PBV.
\end{abstract}

Kata kunci: Profitabilitas, kebijakan hutang, likuiditas, nilai perusahaan

\section{ABSTRACT}

This research investigates the effect of profitability, debt policy, and liquidity on the company's value on property and real estate companies in the Indonesian Stock Exchange. The data in this study is annual data with the period 2010 to 2016. The sampling method used is purposive sampling, which of the population of listed property and real estate companies in the Indonesia Stock Exchange are 49 companies, 32 companies selected as research sample. The independent variables in this research are 
profitability (ROE), liquidity $(C R)$, and debt policy (DER). The dependent variable in this research is a firm value $(P B V)$. The data analysis method used in this research is panel data regression analysis. The results showed that ROE, DER, and CR had a significant effect on PBV simultaneously. Partially ROE and DER have a substantial impact on PBV, whereas $C R$ has no considerable effect on PBV.

Keywords: profitability, debt policy, liquidity, firm value

Naskah diterima : 01-07-2020, Naskah dipublikasikan : 30-09-2020

\section{PENDAHULUAN}

Pada era globalisasi, minat masyarakat Indonesia untuk membeli dan menanamkan investasi di bidang properti dan atau real estate semakin tinggi. Hal ini mendorong peningkatan semakin banyak perusahaan yang mengembangkan usahanya di bidang properti dan real estate. Persaingan menjadi semakin ketat pada bisnis bidang properti yang memaksa setiap perusahaan berusaha meningkatkan daya saingnya. Teori klasik, secara sederhana menyatakan bahwa jumlah tanah di Indonesia tidak akan bertambah. Oleh karena itu harga properti dan real estateakan terus naik dari waktu ke waktu.

Menurut Halim (2005), apabila laba yang diperoleh perusahaan relatif tinggi, maka kemungkinan besar bahwa dividen yang dibayarkan juga relatif tinggi. Apabila dividen yang dibayarkan relatif tinggi, maka akan berpengaruh positif terhadap harga saham di bursa.. Hal ini sesuai dengan bird in the handtheory yang disampaikan oleh (Myron Gordon 1956 dan John Lintner 1962) yang menyatakan bahwa saham perusahaan akan dihargai lebih tinggi jika dividen harapannya lebih tinggi dibandingkan dengan perushaaan yang dividennya lebih rendah. Para investor menjadi lebih tertarik untuk membelinya. Akibatnya permintaan akan saham tersebut menjadi meningkat, sehingga akhirnya nilai perusahaan juga akan meningkat. Nilai perusahaan mencerminkan harga yang akan dibeli investor jika perusahaan dijual. Kekayaan pemegang saham dan perusahaan dicerminkan oleh harga pasar dari saham yang merupakan cerminan dari keputusan investasi, pendanaan, dan manajemen aset. Namun dalam kenyaataannya, ditemukan adanya fakta yang berbeda di lapangan. Beberapa perusahaan properti dan real estate di Indonesia mengalami sebuah fenomena dimana harga saham perusahaan turun ketika laba bersih meningkat atau sebaliknya.

Banyak faktor yang mempengaruhi nilai perusahaan, diantaranya profitabilitas, likuiditas dan kebijakan hutang. Pertama, profitabilitas adalah kinerja keuangan yang menunjukkan kemampuan perusahaan dalam menghasilkan keuntungan dengan menggunakan modal sendiri selama periode tertentu. Salah satu cara untuk mengukur rasio profitabilitas dengan menghitung Return On Equity(ROE) yang menggambarkan kemampuan perusahaan memperoleh laba dengan menggunakan modal sendiri. Dalam penelitian (Hermuningsih, 2013 dan Dewi, et al. 2013) dinyatakanbahwa profitabilitas berpengaruh terhadap nilai perusahaan.

Faktor kedua yang dapat mempengaruhi nilai perusahaan adalah likuiditas. Likuiditas merupakan kemampuan perusahaan untuk membayar kewajiban jangka pendek. Likuiditas berhubungan dengan masalah kemampuan suatu badan usaha untuk memenuhi kebutuhan finansia nya yang segera harus dipenuhi. Manajemen likuiditas harus mampu memberi kontribusi untuk realisasi penciptaan nilai perusahaan (Michalski, 2010). Perusahaan yang memiliki likuiditas yang baik maka akan dianggap 
memiliki kinerja yang baik oleh investor. Hal ini akan menarik minat investor untuk menanamkan modalnya pada perusahaan.

Likuiditas dapat diukur dengan Current Ratio $(C R)$, yang merupakan rasio antara aktiva lancar dibagi hutang lancar (Sartono, 2010). Mahendra (2012) dalam penelitiannya mengungkapkan bahwa likuiditas berpengaruh positif terhadap nilai perusahaan. Hasil serupa diungkapkan Prisilia (2013) yang mengungkapkan bahwa likuiditas berpengaruh terhadap nilai perusahaan. Namun hal berbeda diungkapkan oleh Nurhayati (2013) dan Suwarti (2013) bahwa likuiditas tidak memberi pengaruh pada nilai perusahaan.

Faktor ketiga yang dapat mempengaruhi nilai perusahaan adalah kebijakan hutang. Hutang merupakan pembiayaan yang berasal dari eksternal perusahaan. Kebijakan hutang sendiri merupakan langkah yang diambil manajemen perusahaan untuk mendapatkan sumber pembiayaan dalam membiayai operasi perusahaan. Naik turunnya nilai perusahaan terpengaruh oleh penggunaan hutang. Di satu sisi hutang yang tinggi dapat meningkatkan nilai perusahaan karena penggunaan hutang dapat menghemat pajak. Namun di sisi lain, penggunaan hutang yang tinggi juga dapat menurunkan nilai perusahaan karena timbulnya biaya kepailitan dan biaya keagenan. Dengan demikian, besar kecilnya penggunaan hutang akan berpengaruh terhadap nilai perusahaan. Dalam penelitian Jusriana dan Rahardjo (2013) kebijakan hutang berpengaruh negatif terhadap perusahaan. Namun peneliti lain menyatakan kebijakan hutang tidak berpengaruh dan tidak signifikan terhadap nilai perusahaan (Octavia, 2013). Mardiyati, et al.(2012) kebijakan hutang berpengaruh dan tidak signifikan terhadap nilai perusahaan. Namun saat ditambahkan variabel kontrol kepemilikan manajerial, kebijakan hutang menjadi tidak berpengaruh terhadap nilai perusahaan. Hal ini muncul karena adanya agency problem antara pemegang saham dan manajemen perusahaan.

Pemilihan Sektor perusahaan properti dan real estate menjadi obyek penelitian karena merupakan sektor yang dapat dijadikan tolak ukur pertumbuhan ekonomi suatu negara. Jika kondisi makro ekonomi negara tumbuh pesat maka bisnis properti dan real estate juga mengalami pertumbuhan dan juga sebaliknya. Selain itu, di Indonesia saham sektor properti dan Real Estate merupakan sektor yang memberikan kontribusi besar dan cukup kuat. Pada awal tahun 2014, saham properti menjadi pendorong pertumbuhan tertinggi Indeks Harga Saham Gabungan (IHSG). Indeks sektor ini mampu tumbuh hingga 29,02\% sejak awal tahun 2014 (Aliya, 2014). Namun saat ini, nilai saham properti yang diukur dengan Price Book Value (PBV) menunjukkan tren yang menurun pada 2 tahun terakhir yaitu pada tahun 2015 sebesar 2,31 dan 2014 sebesar 2,56. Nilai PBV tersebut, jauh menurun dibandingan posisi pada pada tahun 2013 yang tercatat sebesar 4,70. Selain itu, berdasarkan pengetahuan penulis, sampai saat ini belum ada yang meneliti permasalahan nilai perusahaan pada perusahaan properti dan real estate dengan menggunakan ketiga variabel independen di atas.

Berdasarkan latar belakang yang telah diuraikan tersebut, maka penulistertarik untuk melakukan penelitian dengan judul : "Pengaruh Profitabilitas, Kebijakan Hutang dan Likuiditas terhadap Nilai Perusahaan Sektor Properti dan Real Estate(Studi Empiris Pada Perusahaan Properti dan Real Estate yang Terdaftar di Bursa Efek Indonesia Tahun 2010-2016). 


\section{KAJIAN LITERATUR}

\section{Teori Keagenan}

Menurut Jensen dan Meckling (1976)) menyatakan bahwa agency problem akan terjadi bila proporsi kepemilikan manajer atas saham perusahaan kurang dari $100 \%$. Kondisi ini mendorong manajer cenderung bertindak untuk mengejar kepentingan untuk dirinya dan sudah tidak berdasarkan maksimalisasi nilai dalam pengambilan keputusan pendanaan. Kondisi tersebut merupakan konsekuensi dari pemisahan fungsi pengelola dengan fungsi kepemilikan, manajemen tidak menanggung risiko atas kesalahan dalam mengambil keputusan. Risiko tersebut sepenuhnya ditanggung pemegang saham (Prinsipal). Oleh karena itu manajemen cenderung melakukan pengeluaran yang bersifat konsumtif dan tidak produktif untuk kepentingan pribadinya, seperti peningkatan gaji dan status.

Dalam pengambilan keputusan pendanaan bagi perusahaan, manajer harus berhati-hati karena keputusan ini dapat berpengaruh terhadap nilai perusahaan. Keputusan pendanaan ini berkaitan dengan kebijakan manajer dalam menentukan proporsi yang tepat antara jumlah hutang dan jumlah modal sendiri di dalam perusahaan sehingga dapat memaksimalkan nilai perusahaan (Rustendi, 2008).

Adanya kepemilikan manajerial menjadi hal yang menarik jika dikaitkan dengan agency theory (Christiawan, 2007). Konflik keagenan bisa dikurangi bila manajer mempunyai kepemilikan saham dalam perusahaan. Manajer yang sekaligus pemegang saham akan berusaha meningkatkan nilai perusahaan, karena dengan meningkatnya nilai perusahaan maka nilai kekayaannya sebagai pemegang saham akan meningkat pula (Sulistiono, 2010).

\section{Nilai Perusahaan}

Menurut Wijaya dan Wibawa (2010), nilai perusahaan didefinisikan sebagai nilai pasar karena nilai perusahaan dapat memberikan kemakmuran pemegang saham secara maksimal apabila harga saham perusahaan meningkat. Semakin tinggi harga saham berarti semakin tinggi tingkat pengembalian kepada investor dan itu berarti semakin tinggi juga nilai perusahaan terkait dengan tujuan dari perusahaan itu sendiri, yaitu untuk memaksimalkan kemakmuran pemegang saham (Gultom, 2013).

Untuk mengetahui nilai pasar perusahaan di mata investor maka digunakan rasio keuangan. Rasio nilai perusahaan memberikan indikasi bagi manajemen mengenai penilaian investor terhadap kinerja perusahaan di masa lampau dan prospekya di masa yang akan datang.

\section{Profitabilitas}

Profitabilitas merupakan kemampuan perusahaan dalam menghasilkan laba. Myers dan Majluf (1984) dalam Octavia (2013) berpendapat bahwa manajer keuangan yang menggunakan pecking order theory dengan laba ditahan sebagai pilihan pertama dalam pemenuhan kebutuhan dana. Selanjutnya, hutang sebagai pilihan kedua dan penerbitan saham sebagai pilihan ketiga yang akan selalu memperbesar profitabilitas untuk meningkatkan laba.

Rasio profitabilitas merupakan ukuran dari kemampuan perusahaan memperoleh laba dalam hubungannya dengan penjualan, total aktiva maupun modal sendiri. Profitabilitas sangat diperhatikan oleh calon investor maupun pemegang saham karena berkaitan dengan harga saham serta dividen yang akan diterima. Jika perusahaan mendapatkan laba dan sebagai timbal balik pemegang saham akan mendapat dividen. Profitabilitasadalah tolak ukur dalam menentukan alternatif pembiayaan. 


\section{Likuiditas}

Likuiditas adalah kemampuan perusahaandalam memenuhi kewajiban jangka pendeknya. Likuiditas jugadapat diartikan sebagai kemampuan seseorang atau perusahaan untukmemenuhi kewajiban atau utang yang harus segera dibayar dengan harta lancarnya. Likuiditas sangat penting bagi suatu perusahaan dikarenakan berkatian dengan mengubah aktiva menjadi kas. Likuiditas sering digunakan oleh perusahan maupun investor untuk mengetahui tingkat kemampuan perusahaan dalam memenuhi kewajibannya.

Brigham dan Houston (2010) mengatakan bahwa aset likuid (liquid asset) merupakan aset yang diperdagangkan pasar aktif sehingga dapat dikonversi dengan cepat menjadi kas pada harga pasar yang berlaku, sedangkan posisi likuiditas suatu perusahaan berkatian dengan pertanyaan, apakah perusahaan mampu melunasi utangnya ketika utang tersebut jatuh tempo pada tahun berikutnya.

\section{Kebijakan Hutang}

Kebijakan hutang adalah kebijakan yang dilakukan perusahaan untuk mendanai operasinya dengan menggunakan hutang keuangan atau yang biasa disebut dengan financial leverage. Leverage keuangan adalah praktik pendanaan sebagian aktiva perusahaan dengan sekuritas yang menanggung beban pengembalian tetap dengan harapan bisa meningkatkan pengembalian akhir bagi pemegang saham (Keown et al. 2010).

Teori yang menjelaskan mengenai kebijakan hutang diantaranya yaitu Trade Off Theory(Myers, 2001) danPecking Order Theory (Donaldson 1961)Trade Off Theory menggambarkan tentang keputusan kontroversi hutang-ekuitas perusahaan antara perlindungan pajak bunga dan biaya masalah keuangan. Nilai perusahaan dengan hutang akan semakin meningkat dengan meningkatnya hutang, tetapi pada titik tertentu nilai tersebut akan turun. Gabungan teori antara teori struktur modal dengan memasukkan biaya kebangkrutan dan biaya keagenan mengindikasikan adanya trade-off antara penghematan pajak dan hutang dengan biaya keuangan. Jadi, diperlukan tingkat hutang yang optimal pada titik tertentu agar nilai perusahaan naik dan tidak timbul biaya kebangkrutan (Hanafi, 2010). Sedangkan Pecking Order Theory menjelaskan mengapa perusahaan akan menentukan hirarki sumber dana yang paling disukai. Menurut Myers dan Manjluf (1984) perusahaan lebih menyukai penggunaaan dana dari modal internal yaitu dana yang berasal dari aliran kas dan laba ditahan. Urutan penggunaan sumber pendanaan menurut Pecking Order Theoryadalah internal fund, debt dan equity.

\section{Penelitian Terdahulu}

Penelitian yang dilakukan oleh (Mardiyati dkk 2012, Faridah 2012, Jusriani dan Rahardjo2013, Mayogi 2016 dan Purnama 2016 menunjukkan bahwa profitabilitas dan kebijakan dividen berpengaruh positif terhadap nilai perusahaan. edangkan kebijakan hutang berpengaruh negatif terhadap nilai perusahaan. Penelitian lain menyatakan hasil yang berbeda khususnya terkait dengan kebijakan hutang yang secara signifikan berpengaruh positif terhadap nilai perusahaan (Taswan 2003, Rustendi dan Jimmy 2008, dan Cheng and Tzeng 2011). Hal ini sesuai dengan Trade of Theory yang dikemukakan oleh Myers yang menyatakan bahwa perusahaan akan berhutang sampai pada tingkat tertentu, dimana penghematan pajak (tax shields) dari tambahan hutang sama dengan biaya kesulitan keuangan (financial distress). Sedang hasil peneliti lain (Mehta 2012, Alfi dan Safarzadeh 2016) menyatakan bahwa struktur modal dan likuiditas mempunyai pengaruh positif dan signifikan terhadap nilai perusahaan. 


\section{KERANGKA PEMIKIRAN DAN HIPOTESIS}

\section{Kerangka Pemikiran}

Sebagaimana dijelaskan pada pendahuluan, penelitian ini akan meneliti pengaruh profitabilitas, likuiditas dan kebijakan hutang terhadap nilai perusahaan pada perusahaan sektor properti dan real estatedengan kerangka pemikiran sebagai berikut:

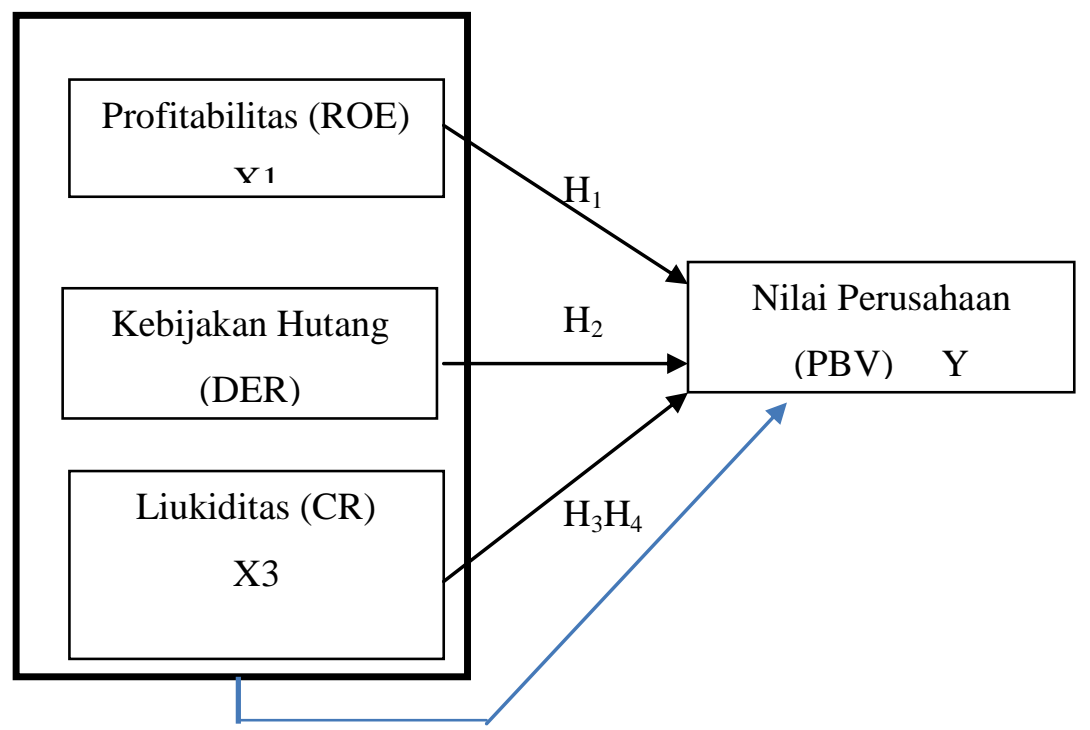

\section{Hipotesis}

Berdasarkan penjelasan mengenai kerangka pemikiran dan paradigma penelitian sebelumnya, maka hipotesis yang diajukan sebagai jawaban sementara terhadap rumusan masalah penelitian ini adalah sebagai berikut :

$\mathrm{H}_{1}$ : Profitabilitas (ROE) berpengaruh positif terhadap Nilai Perusahaan Sektor properti dan real estate.

$\mathrm{H}_{2}$ : Likuiditas (CR) berpengaruh positif terhadap Nilai Perusahaan sektor properti dan real estate.

$\mathrm{H}_{3}$ : Kebijakan Hutang (DER) berpengaruh negatif terhadap Nilai Perusahaan sektor properti dan real estate.

H4: Profitabilitas (ROE), Likuiditas (CR) dan Kebijakan Hutang (DER) secara simultan berpengaruh terhadap nilai perusahaan sektor properti dan real estate. 


\section{METODE PENELITIAN}

\section{Populasi dan Sampel Penelitian}

Populasi dalam penelitian ini adalah seluruh seluruh perusahaan dalam sektor properti dan real estate yang terdaftar di Bursa Efek Indonesia periode 2010-2016 yaitu 49 perusahaan. Teknik pengambilan sampel yang digunakan dalam penelitian ini adalah purposive sampling dengan proses seleksi sebagai berikut:

Tabel 1. Proses Seleksi Sampling

\begin{tabular}{llc}
\hline No & \multicolumn{1}{c}{ Kriteria Sampling } & Total \\
\hline \multirow{1}{1}{} & $\begin{array}{l}\text { Perusahaan properti dn real estate yang terdaftar di } \\
\text { BEI pada periode 2010 -2016 }\end{array}$ & 49 \\
\hline $\mathbf{2}$ & $\begin{array}{l}\text { Perusahaan properti dan Real Estate yang de listing } \\
\text { pada periode 2010 -2016 }\end{array}$ & $(3)$ \\
\hline $\mathbf{3}$ & $\begin{array}{l}\text { Perusahaan yang baru IPO pada periode tersebut } \\
\text { sehingga belum ada laporan keuangan pada periode } \\
\text { 2010 -2016. }\end{array}$ \\
\hline Jumlah perusahaan yang dijadikan sampel & $\mathbf{3 2}$ \\
\hline
\end{tabular}

Sumber : Data olahan peneliti

\section{Type dan Sumber Data}

Data dalam penelitian ini adalah data sekunder yaitu laporan keuangan individual perusahaan properti yang diperoleh dari Bursa Efek Indonesia. Data disusun dalam bentuk data panel. Hal ini karena objek penelitian menggunakan lebih dari satu perusahaan dalam rentang waktu 7 tahun.

\section{Teknis Analisis}

\section{Analisis Regresi Data Panel}

Data panel, yaitu gabungan dari data time series (antar waktu) dan data cross section (antar individu atau ruang), Data time series merupakan data yang dikumpulkan dari waktu ke waktu untuk memberikan gambaran perkembangan suatu kegiatan atau keadaan, sedangkan data cross section adalah data yang dikumpulkan dalam satu waktu tertentu untuk memberikan gambaran perkembangan suatu kegiatan atau keadaan pada waktu itu (Monoppo,2016).

Model regresi dengan menggunakan data panel dapat dilakukan melalui tiga pendekatan, yaitu:

Pooled Least Square (PLS) Model atau Common Effect Model

Merupakan pendekatan model data panel yang paling sederhana karena hanya mengkombinasikan data time series dan cross section. Pada model ini tidak diperhatikan dimensi waktu maupun individu, sehingga diasumsikan bahwa perilaku data perusahaan sama dalam berbagai kurun waktu. Metode ini bisa menggunakan pendekatan Ordinary Least Square (OLS) atau teknik kuadrat terkecil untuk mengestimasi model data panel. 


\section{Model Pendekatan Tetap (Fixed Effects)}

Model ini mengasumsikan bahwa perbedaan antar individu dapat diakomodasi dari perbedaan intersepnya. Untuk mengestimasi data panel model Fixed Effects menggunakan teknik variable dummy untuk menangkap perbedaan intersep antar perusahaan, perbedaan intersep bisa terjadi karena perbedaan budaya kerja, manajerial, dan insentif. Namun demikian slopnya sama antar perusahaan. Model estimasi ini sering juga disebut dengan teknik Least Squares Dummy Variable (LSDV).

\section{Model Pendekatan Efek Acak (Random Effects)}

Model ini akan mengestimasi data panel dimana variabel gangguan mungkin saling berhubungan antar waktu dan antar individu. Pada model Random Effect perbedaan intersep diakomodasi oleh error terms masing-masing perusahaan. Keuntungan menggunakan model Random Effect yakni menghilangkan heterokedastisitas. Model ini juga disebut dengan Error Component Model (ECM) atau teknik Generalized Least Square (GLS).

\section{HASIL DAN PEMBAHASAN}

\section{Analisis Hasil Statistik Deskriptif}

Statistik deskriptif digunakan untuk memberikan gambaran atau deskripsi mengenai suatu data dengan melihat nilai minimum, maksimum, rata-rata, dan deviasi standar. Variabel penelitian ini terdiri dari Return on Equity (ROE), Debt to Equity Ratio (DER), Current Ratio (CR) dan Price to Book Value (PBV) pada perusahaan sektor properti dan real estate dengan diskripsi sebagai berikut:

Tabel 2. Rata-Rata, Median, Maximum, Minimum dan Standar Deviasi

\begin{tabular}{lllllll}
\hline Variabel & N & Mean & Median & Maximum & Mininum & $\begin{array}{l}\text { Std } \\
\text { Deviation }\end{array}$ \\
\hline ROE & 224 & 0.141916 & 0,072982 & 1,36592 & $-0,102938$ & 0.320817 \\
DER & 224 & 0.810237 & 0,654116 & 3,582363 & 0,058462 & 0.710491 \\
CR & 224 & 2.916159 & 1,496639 & 22.19059 & 0.390278 & 4.159446 \\
PBV & 224 & 1.712467 & 1.081448 & 11.23655 & 0,159324 & 2.151093 \\
\hline
\end{tabular}

Sumber : Data BEI 2010 -2016

Berdasarkan tabel 2 di atas, rata-rata ROE perusahaan-perusahaan di sektor properti dan real estate sebesar 14,19 \%. Artinya setiap Rp100 ekuitas pemegang saham perusahaan akan menghasilkan laba sebesar Rp14,19. Untuk rata-rata DER tercatat sebesar 81,02\% yang menunjukkan bahwa perusahaan cukup baik dan berhati-hati dalam mengelola hutangnya. Setiap hutang sebesar Rp81,02 dijamin dengan modal sendiri sebesar Rp.100. Perusahaan sektor properti dan real estate mampu untuk mengelola hutang jangka pendeknya dengan baik. Hal ini tercermin dari rata-rata Current Ratio sebesar 291,61\% yang berarti aset lancar hampir tiga kali lipat hutang lancarnya. Demikian pula untuk kinerja perusahaan yang dicerminkan dengan PBV menunjukkan nilai yang cukup baik. Rata-rata PBV tercatat sebesar 171,24 yang artinya harga saham lebih besar 1,7124 kali dibandingkan dengan nilai buku ekuitas yang dimiliki perusahaan untuk setiap lembar sahamnya. 


\section{Pemilihan Model Regresi Data Panel}

Untuk memilih model yang paling tepat dari tiga model regresi data panel dilakukan tahapan test sebagai berikut :

\section{Uji Chow test}

Uji chow merupakan pengujian untuk menentukan model yang paling tepat digunakan dalam mengestimasi data panel model antara Pooled Least Square(OLS) dengan Fixed EffectModel (FEM).

Redundant Fixed Effects Tests

\section{Tabel 3. Hasil Uji Chow}

Pool: POOL_FIXED

Test cross-section fixed effects

\begin{tabular}{lrrr}
\hline \hline Effects Test & Statistic & d.f. & Prob. \\
\hline \hline Cross-section F & 4.703293 & $(31,189)$ & 0.0000 \\
Cross-section Chi-square & 128.081525 & 31 & 0.0000 \\
\hline \hline
\end{tabular}

Berdasarkan hasil uji chow didapat nilai probabilitas 0.0000. Nilai Probabilitas lebih kecil daripada level signifikan $(\alpha=0.05)$ sehingga estimasi yang lebih baik digunakan dalam model ini adalah fixed effect.

\section{Hausman test}

Tahapan selanjutnya untuk melakukan uji spesifikasi dengan menggunakan ujiHausman.Pengujian ini bertujuan mencari model yang tepat dan lebih efisien antara Fixed EffectModel(FEM) atau dengan Random Effect Model(REM).

\section{Tabel 4. Hasil Uji Hausman}

Correlated Random Effects - Hausman Test

Pool: POOL_RANDOM

Test cross-section random effects

\begin{tabular}{llll}
\hline \hline Test Summary & $\begin{array}{l}\text { Chi-Sq. } \\
\text { Statistic }\end{array}$ & Chi-Sq. d.f. & Prob. \\
\hline \hline Cross-section random & 10.357457 & 3 & 0.0158 \\
\hline \hline
\end{tabular}

Berdasarkan hasil uji hausman didapat nilai probabilitas 0.0158. Nilai Probabilitas lebih kecil daripada level signifikan $(\alpha=0.05)$, maka model terbaik adalah fixed effect model. 


\section{Analisis Regresi Data Panel}

Tabel 5. Uji Fixed Effect Model

\begin{tabular}{lccc}
\hline Variabel & Koefisien & t-statistic & Prob. \\
\hline Konstanta & -0.053054 & -0.238159 & 0.8120 \\
ROE & 1.346393 & 5.287162 & $0.0000 * * *$ \\
DER & 1.858746 & 7.949860 & $0.0000 * * *$ \\
CR & 0.023463 & 0.863565 & 0.3889 \\
\hline R-Squared & 0.708008 & & \\
Adjusted R-Squared & 0.655480 & & \\
F-Statistic & 13.47877 & & \\
Prob (F-Statistic) & 0.000000 & \\
\hline \multicolumn{4}{c}{$* *, * * *$ level signifikan pada $10 \%, 5 \%$ and $1 \%$}
\end{tabular}

Secara parsial, hasil pengujian sebagai berikut:

\section{Pengaruh profitabilitas terhadap nilai perusahaan}

Hasil regresi pada tabel 5 menunjukkan bahwa nilai koefisien ROE sebesar 1.346393 dengan nilai probabilitas sebesar 0.0000. Hasil ini mengindikasikan p-vaule $0,0000<\alpha 0.05$. Dengan demikan, $\mathrm{H}_{1}$ diterima yaitu ROE berpengaruh positif dan signifikan terhadap PBV.

\section{Pengaruh kebijakan hutang terhadap nilai perusahaan.}

Hasil regresi pada tabel 5 menunjukkan bahwa nilai koefisien DER sebesar 1.858746 dengan nilai probabilitas sebesar 0.0000. Hasil ini mengindikasikan p-vaule $0,0000<\alpha \quad 0.05$. Dengan demikian $\mathrm{H}_{2}$ diterima namun arahnya berbeda karena pengaruh positif DER terhadap PBV.

\section{Pengaruh Likuiditas terhadap nilai perusahaan.}

Hasil regresi pada tabel 5 menunjukkan bahwa nilai koefisien CR sebesar 0.023463 dengan H3nilai probabilitas 0.3889 . Hasil ini mengindikasikan p-vaule $0,3889>\alpha 0.05$. Dengan demikian $\mathrm{H}_{3}$ ditolak karena CR bepengaruh positif dan tidak signikan terhadap PBV.

Pengaruh profitabilitas, kebijakan hutang dan Likuditas secara simulta, n terhadap nilai perusahaan.

Hasil regresi pada tabel 5 menunjukkan Nilai Prob (F-Statistic) $0.000000<0.05$. Artinya secara simultan variabel Profitabilitas (ROE), Kebijakan Hutang (DER), Likuiditas (CR) berpengaruh signifikan terhadap nilai perusahaan (PBV) pada perusahaan Properti dan Real Estate periode 2010-2016. Dengan demikian $\mathrm{H}_{4}$ diterima. 


\section{Koefisien Determinasi}

Dari tabel 5 dapat dilihat bahwa koefisien $\left(\mathrm{R}^{2}\right)$ yaitu sebesar 0.708008 atau $70.8 \%$. Berdasarkan tabel tersebut, maka dapat disimpulkan bahwa seluruh variabel bebas Return On Equity (ROE), Debt to Equity Ratio (DER), Currrent Ratio (CR) dapat menjelaskan variabel terikat Price to Book Value (PBV) sebesar $70,8 \%$ sedangkan sisanya sebesar $29,2 \%$ dipengaruhi oleh faktor-faktor lain yang tidak dimasukkan dalam model penelitian ini.

\section{PEMBAHASAN}

\section{Analisis Pengaruh Profitabilitas terhadap Nilai Perusahaan}

Hasil penelitian ini menunjukkan bahwa variabel profitabilitas yang diukur dengan Return On Equity (ROE) memiliki pengaruh positif dan signifikan terhadap nilai perusahaan pada perusahaan Properti dan Real Estate periode tahun 2010-2016. Kenaikan laba perusahaan menjadi sinyal positif bagi investor karena menjadi indikasi bahwa kinerja perusahaan semakin membaik. Kondisi ini mendorong kenaikan harga saham yang pada gilirannya akan menaikkan harga saham.

Hasil ini serupa dengan penelitian yang dilakukan oleh Mardiyati et.al (2012) yang menyatakan bahwa profitabilitas (ROE) berpengaruh positif dan signifikan terhadap Nilai Perusahaan (PBV). Dengan demikian, hasil penelitian menjawab hipotesa $\mathrm{H} 1$ yaitu profitabilitas berpengaruh positif dan signifikan terhadap nilai perusahaan properti dan real estate.

\section{Analisis Pengaruh Kebijakan Hutang terhadap Nilai Perusahaan}

Hasil penelitian ini menunjukkan bahwa variabel kebijakan hutang yang diukur dengan Debt to Equity Ratio (DER) memiliki pengaruh positif dan signifikan terhadap nilai perusahaan pada perusahaan Properti dan Real Estate. Hasil ini berbeda dengan hipotesis H2 yaitu DER berpengaruh negatif terhadap nilai perusahaan. Namun perbedaan tersebut, dapat dijelaskan bahwa sesuai dengan karakteristik bisnis di bidang properti dan real estate untuk pendanaan lebih banyak menggunakan hutang dibandingkan modal sendiri.

Berdasarkan hasil penelitian menggambarkan bahwa perusahaan di bidang properti dan real estate mampu mengelola dengan baik hutangnya ke dalam aset-aset yang produktif sehingga memberikan keuntungan yang lebih besar dibandingkan dengan biaya hutang yang harus ditanggungnya. Penggunaan hutang ini sesuai dengan Pecking Order Theory (POT) yaitu hutang lebih disukai dibanding pendanaan dengan penerbitan saham karena adanya penghematan pajak. Hanafi (2010) mengatakan bahwa perusahaan harus mengatur hutang pada tingkat yang optimal agar mendorong kenaikan nilai perusahaan dan menghindari kebangkrutan. Hasil ini sesuai dengan penelitian yang dilakukan oleh Taswan (2003) yang menyatakan bahwa dengan penggunaan hutang akan meningkatkan nilai perusahaan

\section{Analisis Pengaruh Likuiditas terhadap Nilai Perusahaan}

Hasil penelitian ini menunjukkan bahwa variabel likuiditas yang diukur dengan Current Ratio (CR) memiliki pengaruh positif tetapi tidak signifikan terhadap nilai perusahaan pada perusahaan Properti dan Real Estate periode tahun 2010-2016. Pengaruh positif ini menunjukkan bahwa semakin tinggi nilai 
likuiditas perusahaan akan semakin tinggi nilai perusahaan dan sebaliknya. Hasil penelitian ini sesuai dengan Hipotesis yaitu Likuiditas berpengaruh positif terhadap nilai perusahaan properti dan real estate. Namun demikian pengaruhnya tidak signifikan terhadap nilai perusahaan. Hasil ini diperkuat dengan penelitian yang dilakukan oleh Firnanda (2016) yang menyatakan bahwa likuiditas berpengaruh positif dan tidak signifikan terhadap Nilai Perusahaan (PBV).

Berdasarkan hasil penelitian ini maka perusahaan-perusahaan di sektor properti dan real estate untuk meningkat kinerjanya harus berupaya untuk terus meningkatkan profitabilitasnya karena memberikan dampak positf bagi kinerja perusahaan. Namun demikian, upaya mengejar keuntungan tersebut juga harus diimbangi dengan pengaturan yang baik dan berhati-hati dalam pengelolaan hutang dan current ratio pada batas yang wajar yaitu hutang yang sesuai kebutuhan perusahaan. Hutang yang berlebihan dan juga current ratio yang terlalu tinggi akan memberikan dampak negatif pada pencapaian kinerja perusahaan. Apabila hal tersebut dapat dilakukan dengan baik maka kinerja perusahaan akan meningkat sehingga menarik minat para investor untuk menamamkan investasinya ke perusahaaan.

\section{PENUTUP}

\section{Simpulan}

Tujuan penelitian ini adalah untuk memperoleh pengaruh profitabilitas, kebijakan hutang dan likuiditas terhadap nilai perusahaan sektor properti dan real estate di Indonesia selama periode 2010 2016. Hasil penelitian menunjukkan bahwa dua variabel independen yaitu profitabilitas (ROE) dan kebijakan hutang (DER) berpengaruh signifikan terhadap nilai perusahaan (PBV). Sedangkan likuiditas (CR) tidak berpengaruh signifikan terhadap nilai perusahaan sektor properti dan real estate. Pada kebijakan hutang menunjukkan hasil yang berbeda dengan hipotesis karena ternyata pengaruhnya positif terhadap nilai perusahaan.

Hasil penelitian ini menunjukkan bahwa kemampuan perusahaan untuk meningkatkan laba dan mengoptimal penggunaan hutang akan memberikan pengaruh pada semakin meningkatnya nilai perusahaan pada sektor properti dan real estate. Meningkatnya laba memberikan peluang perusahaan untuk membagikan deviden yang lebIh besar kepada peemegang saham. Hal ini menjadi sinyal positif akan kinerja perusahaan yang semakin membaik. Demikian pula, kemampuan perusahaan mengelola hutang dengan baik dan berhati-hati yaitu pada struktur modal yang optimal akan memberikan keuntungan lebih besar dibandingkan biaya hutang yang harus dibayar. Peningkatan profitabilitas dan kemampuan memberdayakan hutang menjadi dorongan untuk peningkatan nilai perusahaan.

Penelitian ini memiliki keterbatasan karena pertama, hanya meneliti pada perusahaan sektor properti dan real estate sehingga tidak dapat digunakan untuk sektor industri yang lain. Kedua, hanya tiga variabel independen yaitu profitabilitas, kebijakan hutang dan likuidItas sehinga ada kemungkinan ada beberapa variabel lain yang juga signifikan mempengaruhi nilai perusahaan di sektor properti dan real estate. Terakhir, jangka waktu penelitian cukup pendek yaitu dari 2010 -2-16. 


\section{Saran}

Adapun saran yang dapat dijadikan masukan kepada emiten, investor dan peneliti lainnya sebagai berikut Bagi manajemen perusahaan di sektor properti dan real estate agar memfokuskan pada peningkatan laba perusahaan dan pengelolaan hutang yang baik karena mempunyai pengaruh signifikan terhadap nilai perusahaan.Bagi investor untuk selalu menganalisis laporan keuangan perusahaan khususnya pada profitabilitas dan struktur permodalan sebagai indikasi kinerja perusahaan di sektor properti dan real estate.Bagi peneliti selanjutnya, disarankan untuk menambah variabel independen lain seperti Dividend Payout Ratio, Size,Kepemilikan Manajerial, dan Corporate Governance.

\section{REFERENSI}

Brigham, E.F., and Houston, J.F. 2014."Dasar-Dasar Manajemen Keuangan (Essentials of Financial Management)".Edisi 11, Buku 2. Jakarta: Salemba Empat.

Cheng, Ming-Chang dan Tzeng, Zuwe-Chin. 2011, The Effect of Leverage on Firm Value and How the Firm Financial Quality Influence on This Effect, World Journal of Management, Vol 3, No.2, hal $30-53$.

Christiawan, Y.J. \& Tarigan, J. 2007. Kepemilikan Manajerial: Kebijakan Hutang, Kinerja dan Nilai Perusahaan. Jurnal Akuntansi dan Keuangan.Vol.1, Hal:1-8.

Donaldson, G. 1961. Corporate Debt Capacity: A study of Corporate Debt Policy and the Determination of Corporate Debt Capacity. Boston, Division of Research, Harvard Graduate School of Business Administration

Dewi, A.\& Wirajaya, A. 2013.'Pengaruh Struktur Modal, Profitabilitas dan Ukuran Perusahaan pada Nilai Perusahaan.”E-Jurnal Akuntansi Universitas Udayana.Vo.4,No.2, Hal.358-372

Faridah Z.N. 2012, Kebijakan Deviden, Hutang, Investasi Dan Pengaruhnya Terhadap Nilai Perusahaan Pada Perusahaan Manufaktur, Journal of Business and Banking, Vol 2, No.1.

Gultom, R. 2013. Analisis Faktor-Faktor Yang Mempengaruhi Nilai Perusahaan Pada Perusahaan Farmasi Di Bursa Efek Indonesia. Jurnal Wira Ekonomi Mikroskil, Vol. 3, No. 1, Hal: 51-60.

Halim, A. 2005. Analisis Investasi. Edisi Kedua. Jakarta : Salemba Empat.

Hanafi, M. M. (2010). Manajemen Keuangan. Cetakan ke lima. Yogyakarta: BPFE.

Hermuningsih, S.. 2014. Profitability, Growth Opportunity, Capital Structure and The Firm Value. Bulletin of Monetary, Economics and Banking.

Indahningrum, R.P. dan Handayani, R. 2009. Pengaruh Kepemilikan Manajerial, Kepemilikan Institutional, Deviden, Pertumbuhan Perusahaan, Free Cash Flow,dan Profitabilitas terhadap Kebijakan Hutang Perusahaan.Jurnal Bisnis dan Akuntansi Vol. 11(3): 189-207.

Jusriani, I.F. 2013. Analisis Pengaruh Profitabilitas, Kebijakan Dividen, Kebijakan Hutang, dan Kepemilikan Manajerial terhadap Nilai Perusahaan (Studi Empiris pada Perusahaan Manufaktur yang Terdaftar di Bursa Efek Indonesia Periode 2009-2011). Semarang: Universitas Diponegoro. 
Keown, A.J., John D. Martin, J. William P dan David F.J. 2010. Manajemen Keuangan: Prinsip dan Penerapan Jilid 2. Jakarta: Indeks.

Mahendra, A.2011. Pengaruh Kinerja Keuangan terhadap Nilai Perusahaan pada Perusahaan Manufaktur di BEI.Jurnal Manajemen, Strategi Bisnis, dan Kewirausahaan 6 (2): 130-138.

Mardiyati, U. Gatot N.A., dan Ria P. 2012. Pengaruh Kebijakan Dividen, Kebijakan, Hutang dan Profitabilitas terhadap Nilai Perusahaan Manufaktur yang Terdaftar di Bursa Efek Indonesia (BEI) periode 2005-2010. Jurnal Riset Manajemen Sains Indonesia (JRMSI), 3 (1), h: 1-17.

Manoppo,P.M. 2016. "Pengaruh Makro-Ekonomi Terhadap Return Saham PerusahaanOtomotif Dengan Profitabilitas Sebagai Variabel Mediasi”. Tesis. Program Studi Magister Manajemen, Program Pascasarjana. Universitas MercuBuana. Jakarta.

Mayogi, D.G.\& Fidiana, 2016, Pengaruh Profitabilitas, Kebijakan Deviden, Dan Kebijakan Hutang Terhadap Nilai Perusahaan, Jurnal Ilmu dan Riset Akuntansi, Vol.5, No.1.

Myers, S. C. dan Majluf, N.S. 1984. Corporate Financing \& Investment Decision When Firm Have Information That Investor Do Not Have.Journal of Financial Economics, 13 pp 187-221.

Michalski G. (2010), „Entrepreneurial strategic financial liquidity management”, CeDeWu, Warszawa

Nurhayati, M. 2013. Profitabilitas, Likuiditas dan Ukuran Perusahaan Pengaruhnya terhadap Kebijakan Dividen dan Nilai Perusahaan Sektor Non Jasa. Jurnal Keuangan dan Bisnis. 5(2) .

Octavia, L. 2013. Analisis Pengaruh Kebijakan Hutang, Dividen, Profitabilitas dan Ukuran Perusahaan terhadap Nilai Perusahaan Manufaktur di BEI periode 2008-2012. Skripsi. Universitas Diponegoro.

Purnama, H. (2016). pengaruh profitabilitas, kebijakan hutang, kebujakan deviden, dan keputusan investasi. Jurnal Akuntansi, Vo; 4, No.1, hal 31-48.

Prisilia R.G.. 2013. Likuiditas, Solvabilitas dan Rentabilitas terhadap Nilai Perusahaan BUMN yang terdaftar di Bursa Efek Indonesia. Jurnal EMBA. $1 \quad$ (3) h : 252-262.

Rustendi, T. dan Farid J. 2008. Pengaruh Hutang dan Kepemilikan Manajerial Terhadap Nilai Perusahaan Pada Perusahaan Manufaktur (Survey Pada Perusahaan Manufaktur yang Tercatat di Bursa Efek Jakarta). Jurnal Akuntansi FE Universitas Siliwangi, 3(1), 2008.

Sartono, A. 2000. Ringkasan teori Manajemen Keuangan Soal dan Penyelesaiannya. Edisi 3. Yogyakarta. BPFE.

Sulistiono. 2010. Pengaruh Kepemilikan Manajerial, Struktur Modal dan Ukuran Perusahaan Terhadap Nilai Perusahaan Pada Perusahaan Manufaktur di BEI Tahun 2006-2008. Skripsi : Fakultas Ekonomi Universitas Negeri Malang.

Suwarti, T., Sunarto, L., Widati W, \& Sianto, IO. 2013. Pengaruh Kinerja Keuangan terhadap Nilai Perusahaan dengan Kinerja Lingkungan sebagai Variabel Moderasi. Laporan Penelitian Intern.Universitas Stikubank Semarang.

Taswan.2003."Analisis Pengaruh Insider Ownership, Kebijakan Hutang dan Dividen Terhadap Nilai Perusahaan Serta Faktor -Faktor Yang Mempengaruhinya." Jurnal Bisnis dan Ekonomi. 
Taurisina F. dan Hening W.O. 2016. Analisis Likuiditas, Profitabilitas, Solvabilitas dan Perputaran Persediaan Terhadap Nilai Perusahaan. Jurnal Ilmu dan Riset Manajemen, 5(2), Pp.1 - 15.

Wijaya, L.R.P. \& Wibawa, B.A. 2010. Pengaruh Keputusan Investasi, Keputusan Pendanaan, dan Kebijakan Dividen Terhadap Nilai Perusahaan. Jurnal SNA 13 Purwokerto.

http://www.idx.co.id/

http://www.finance.yahoo.com/ 